\title{
Regulatory Role of Endothelial PHD2 in the Hepatic Steatosis
}

\author{
Li-Ying Zhou ${ }^{a, b}$ Heng Zeng ${ }^{a}$ Shuo Wanga,c Jian-Xiong Chen ${ }^{a}$ \\ ${ }^{a}$ Department of Pharmacology and Toxicology, University of Mississippi Medical Center, School \\ of Medicine, Jackson, MS, USA, bepartment of Reproduction, Beijing Obstetrics and Gynecology \\ Hospital, Capital Medical University, Beijing, "Key laboratory of cerebral cardiopulmonary Resuscitation, \\ Beijing Chao-Yang Hospital, Capital Medical University, Beijing, China
}

\section{Key Words}

Phd2 • HIF-2 $\alpha$ Endothelium • Hepatic Steatosis • Atrial natriuretic peptide (ANP)

\begin{abstract}
Background/Aims: Liver disease is a leading cause of high mortality and morbidity worldwide. The aim of the present study is to investigate the regulatory role of prolyl hydroxylase-2 (PHD2)-hypoxia-inducible factor-2 $\alpha$ (HIF-2 $\alpha$ ) axis on nonalcoholic fatty liver disease (NAFLD) and to explore the potential mechanisms by which endothelial (EC)-specific PHD2 deficiency regulates hepatic steatosis and fibrosis. Methods: In the endothelial-specific PHD2 knockout (PHD2 $\left.{ }^{\mathrm{EC}} \mathrm{KO}\right)$ mouse fed with normal diet or high fat diet (HFD), liver lipid accumulation and fibrosis were measured by Oil Red $\mathrm{O}$ and Masson trichrome staining. The fat and body weight (FW/BW) ratio and glucose tolerance were measured. The expression of HIF-2 $\alpha$, atrial natriuretic peptide (ANP), angiopoietin-2 (Ang-2), and transforming growth factor- $\beta$ (TGF- $\beta$ ) were analyzed by western blot analysis. Results: The steatosis and fibrosis were significantly increased in the PHD2 ${ }^{\mathrm{EC}} \mathrm{KO}$ mice. FW/BW ratio was significantly increased in the PHD2 ${ }^{\mathrm{EC}} \mathrm{KO}$ mice. Moreover, knockout of endothelial PHD2 resulted in an impairment of glucose tolerance in mice. Western blot analysis showed that the expression of HIF-2 $\alpha$ in liver tissues was not significantly increased. Interestingly, the expression of ANP was decreased, and Ang-2 and TGF- $\beta$ levels were significantly increased in the liver of PHD2 ${ }^{\mathrm{EC}} \mathrm{KO}$ mice. The FW/BW ratio was also significantly increased in the PHD2 ${ }^{\mathrm{EC}} \mathrm{KO}$ mice fed with HFD for 16 weeks. Feeding HFD resulted in a significant increase in hepatic steatosis in the control PHD2 ${ }^{\mathrm{fff}}$ mice, but did not further enhance hepatic steatosis in the PHD2 ${ }^{\mathrm{EC}} \mathrm{KO}$ mice. Conclusions: We concluded that the endothelial PHD2 plays a critical role in hepatic steatosis and fibrosis, which may be involved in the regulation of ANP and Ang-2/TGF- $\beta$ signaling pathway, but not the HIF-2 $\alpha$ expression.
\end{abstract}




\section{Cellular Physiology Cell Physiol Biochem 2018;48:1003-1011 and Biochemistry Published online: July 23, $2018 \quad \begin{aligned} & \text { DOI: 10.1159/000491968 } 2018 \text { The Author(s). Published by S. Karger AG, Basel } \\ & \text { www.karger.com/cpb }\end{aligned}$ Zhou et al.: Endothelial PHD2 and Hepatic Steatosis}

\section{Introduction}

The prevalence of nonalcoholic fatty liver disease (NAFLD) is increasing at an alarming rate, therefore, it is urgent to identify potential therapeutic targets. Fatty liver disease (FLD), which is a major cause of chronic liver disease worldwide [1,2], initially begins with simple hepatic steatosis but can irreversibly progress to steatohepatitis, fibrosis, cirrhosis, or hepatocellular carcinoma. Recent studies have revealed that fat accumulation in the liver clearly predisposes the liver to injury and progresses to FLD $[3,4]$. Thus, hepatic steatosis is a key step in the development and progression of NAFLD. Hypoxia is closely associated with lipid homeostasis. Studies reveal that ischemic and hypoxic stress increases cellular lipid deposition both in vitro and in vivo [5-7]. Hypoxia also upregulates genes involved in lipogenesis, lipid uptake, and lipid droplet formation [8-10]. In addition, several studies have implicated the crucial role of hypoxia and hypoxia inducible factors (HIFs) in lipid homeostasis [11-13].

Prolyl hydroxylase domain enzymes (PHD) are the oxygen sensing molecules that form a complex von Hippel-Lindau protein (VHL) and degrade HIF- $\alpha$ [14-17]. In three PHD isoforms, PHD2 is considered as the most important HIF- $\alpha$-regulating isoform [18-20]. Our recent studies indicate the expression of PHD2 in endothelial cells has a critical role in the regulation of vascular remodeling and the development of fibrosis by the mechanism involving in upregulation of HIF-2 $\alpha$ expression in lung and kidney [21, 22]. Accumulating evidence suggests some of hypoxia-associated genes were not regulated by HIFs, implicating potential HIF-independent pathways that are controlled by prolyl hydroxylase domain (PHD) enzymes [23]. PHD2 has many aspects that are not explained by HIF-mediated mechanisms alone. A recent study revealed that PHD2 could control both HIF-dependent and HIFindependent hypoxia responses [24]. In the present study, we test whether specific knockout of endothelial PHD2 regulates hepatic steatosis and fibrosis via a HIF- $2 \alpha$-independent pathway in adult mice.

Using an endothelial-specific PHD2 knockout (PHD2 ${ }^{\mathrm{EC}} \mathrm{KO}$ ) mouse with normal diet or high-fat diet (HFD), we investigate the regulatory role of endothelial PHD2-HIF-2 $\alpha$ signaling pathway in NAFLD and explore the potential mechanisms end othelial PHD2 regulates hepatic steatosis and fibrosis. Our data demonstrated that specific deletion of PHD2 in endothelium promoted hepatic steatosis and fibrosis via downregulation of atrial natriuretic peptide (ANP) and upregulation of angiopoietin-2 (Ang-2)/ transforming growth factor- $\beta$ (TGF- $\beta$ ) in a HIF- $2 \alpha$-independent mechanism.

\section{Materials and Methods}

\section{Ethics Statement}

Experimental animals were fed with laboratory standard chow and water and housed in individually ventilated cages in the Laboratory Animal Facilities (LAF) at the University of Mississippi Medical Center. All procedures conformed to the Institute for Laboratory Animal Research Guide for the Care and Use of Laboratory Animals and were approved by the University of Mississippi Medical Center Animal Care and Use Committee (Protocol ID: 1280B). The investigation conforms to the Guide for the Care and Use of Laboratory Animals published by the US National Institutes of Health (NIH Publication No. 85-23, revised 1996).

\section{Generation of the PHD2 $2^{\text {flox/flox(f/f) }}$ and $P H D 2^{E C} K O$ mice}

$\mathrm{PHD}^{\text {flox/flox }}\left(\mathrm{PHD}^{\mathrm{f} / \mathrm{f}}\right)$ mice were obtained from Dr. Guo-hua Fong at University Connecticut. PHD2 ${ }^{\mathrm{EC}} \mathrm{KO}$ mice were generated using the Cre-LoxP system as previous described [21, 22]. The absence of PHD2 in vascular endothelium was confirmed by western blot analysis using cultured endothelial cells (EC) isolated from $\mathrm{PHD} 2^{\mathrm{EC}} \mathrm{KO}$ mice.

\section{HFD model}

$\mathrm{PHD}^{\mathrm{f} / \mathrm{f}}$ and PHD2 ${ }^{\mathrm{EC}} \mathrm{KO}$ mice (8 weeks of age) were fed with normal chow diet or high-fat (60\% kcal) diet (D12492; Research Diets (New Brunswick, NJ, USA) for 16 weeks to produce a HFD model. Mice were housed in the LAF and were given free access to water throughout the study. 


\section{Cellular Physiology Cell Physiol Biochem 2018;48:1003-1011 and Biochemistry Published online: July 23, $2018 \quad \begin{aligned} & \text { DOI: 10.1159/000491968 } 2018 \text { The Author(s). Published by S. Karger AG, Basel } \\ & \text { www.karger.com/cpb }\end{aligned}$ \\ Zhou et al.: Endothelial PHD2 and Hepatic Steatosis}

\section{Western Blot Analysis}

Mouse liver tissues were homogenized in $300 \mu \mathrm{L}$ of an ice-cold lysis buffer. The homogenates were centrifuged at $4,500 \mathrm{rpm}$ for 5 minutes at $4^{\circ} \mathrm{C}$ and the total protein concentrations were determined using a BCA protein assay kit (Pierce Co, IL). An aliquot (30 $\mu \mathrm{g}$ ) of the protein lysate was separated on $10 \%$ SDSPAGE gel and transferred to a membrane by electrophoresis. The membranes were blocked with $5 \%$ nonfat dry milk in Tris-buffered saline and incubated with the following primary antibodies overnight: HIF-2 $\alpha$, ANP, Akt, and 6-phosphofructo-2-kinase/fructose-2, 6-biphosphatase-3 (PFKFB3) (1:1000, Novus Bio, CO); transforming growth factor (TGF)- $\beta$ and Ang-2 (1:1000, Sigma, M0). The membranes were then washed and incubated for $2 \mathrm{hrs}$ with an anti-rabbit or anti-mouse secondary antibody conjugated with horseradish peroxidase (1:5000, Santa Cruz, CA). Densitometric analysis of the bands was carried out using image acquisition and analysis software (TINA 2.0).

\section{Histological Analysis}

Live tissues were fixed with buffered 10\% formalin solution (SF93- 20; Fisher Scientific, Pittsburgh, $\mathrm{PA}$ ), embedded in frozen optimal-cutting-temperature compound, and $10 \mu \mathrm{m}$ frozen sections prepared. Some sections were stained with Hematoxylin \& eosin (H \& E), and some sections were stained with Oil Red 0 working solution for lipid analysis $[25,26]$. Masson trichrome staining was also performed on adjacent sections to measure the degree of fibrosis. The area percentage of lipid or fibrosis was quantified by measuring 6 random microscopic fields using image-analysis software (Image J, NIH).

\section{Measurement of body fat accumulation}

At the end of experiments, animals were sacrificed and fat from abdominal tissue was collected and weighted. Fat weight/body weight ratio (FW/BW) was calculated.

\section{Glucose tolerance test}

$\mathrm{PHD}^{\mathrm{f} / \mathrm{f}}$ and PHD2 ${ }^{\mathrm{EC}} \mathrm{KO}$ mice (24 weeks of age) were subjected to glucose tolerance test. Glucose tolerance test was carried out after a 12 hour fast by intraperitoneal injection with D-glucose $(1 \mathrm{mg} / \mathrm{g})$ in sterile saline. Blood was obtained from experimental mice by tail snip, and blood glucose levels were measured with One Touch SureStep test strips. Glucose levels were expressed as mg/dL.

\section{Statistical Methods}

Mean \pm SD are presented. The significance of differences in the means of corresponding values between groups were determined using the independent samples t test. A p $<0.05$ was considered to be significant.

\section{Results}

$P H D 2{ }^{E C} K O$ increases hepatic steatosis and downregulates ANP, PFKFB3, and Akt expression

Oil Red $O$ staining of liver tissues showed that the fat is significantly increased in the PHD ${ }^{\mathrm{EC}} \mathrm{KO}$ mice (Fig. 1A). We examined HIF-2 $\alpha$ in liver tissues and found there was no significantly increased HIF- $2 \alpha$ levels in the PHD ${ }^{\mathrm{EC}} \mathrm{KO}$ mice (Fig. 1B). In contrast, the expression of PFKFB3 and Akt was significantly decreased in the PHD2 ${ }^{\mathrm{EC}} \mathrm{KO}$ mice (Fig. 1C and 1D). Most intriguingly, atrial natriuretic peptide (ANP), a peptide hormone secreted from cardiomyocyte and endothelium, was significantly reduced in the liver of the PHD2 ${ }^{\mathrm{EC}} \mathrm{KO}$ mice (Fig. 1E).

\section{PHD2 ${ }^{E C}$ KO upregulates Ang-2/TGF- $\beta$ pathway and increases hepatic fibrosis}

We used Masson trichrome staining to detect the fibrosis of liver. Fibrosis was found in the perivascular region of small arteries and venous, especially in the PHD2 ${ }^{\mathrm{EC}} \mathrm{KO}$ mice. The percentage of fibrotic area increased significantly compared with the control PHD2 ${ }^{\mathrm{f} / \mathrm{f}}$ mice (Fig. 2A). The expression of Ang-2 increased significantly by PHD2 knockout in endothelium. TGF- $\beta$, which has contributed to liver fibrosis, was increased significantly by

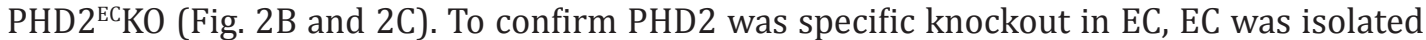
from PHD2 ${ }^{\mathrm{EC}} \mathrm{KO}$ mice and control PHD2 ${ }^{\mathrm{f} / \mathrm{f}}$ mice, and PHD2 was analyzed. As shown in Fig. 
2D, PHD2 expression was abolished in the EC from PHD2 ${ }^{\mathrm{EC}} \mathrm{KO}$ mice.

PHD2 ${ }^{E C} K O$ increases body fat
accumulation and impairs
glucose tolerance in mice
We measured body fat accumulation using the index of fat weight and body weight ratio (FW/ BW ratio). As shown in Fig. 3A, PHD2 ${ }^{\mathrm{EC}} \mathrm{KO}$ mice fed with normal diet had a significant increase in FW/BW ratio as compared with the control PHD2 ${ }^{\mathrm{f} / \mathrm{f}}$ mice. Glucose tolerance test further showed that glucose tolerance was impaired in PHD2 ${ }^{\mathrm{EC}} \mathrm{KO}$ mice compared with the control PHD2 $2^{\mathrm{f} / \mathrm{f}}$ mice challenged with glucose on normal diet (Fig. 3B).

Roles of $P H D 2^{E C} K O$ on HFDinduced body fat accumulation and hepatic steatosis

Next, we examined the effects of endothelial PHD2 on HFD-induced hepatic steatosis. As shown in Fig. 3A, PHD2 ${ }^{\mathrm{EC}} \mathrm{KO}$ mice fed with high-fat diet for 16 weeks led to a significant increase in $\mathrm{FW} / \mathrm{BW}$ ratio as compared with $\mathrm{PHD} 2{ }^{\mathrm{EC}} \mathrm{KO}$ mice fed with normal diet. PHD2 ${ }^{\mathrm{f} / \mathrm{f}}$ mice fed with high-fat diet resulted in a significant increase in hepatic steatosis (red oil stain) and FW/ BW ratio (Fig. $1 \mathrm{~A}$ and Fig. 3A). Surprisingly, the hepatic steatosis was not further exacerbated in the PHD2 ${ }^{\mathrm{EC}} \mathrm{KO}$ mice fed with HFD as compared with PHD2 ${ }^{\mathrm{EC}} \mathrm{KO}$ mice fed with normal diet (Fig. 1A). Also, hepatic fibrosis was not significantly different between the control $\mathrm{PHD}^{\mathrm{f} / \mathrm{f}}$ mice and PHD2 ${ }^{\mathrm{EC}} \mathrm{KO}$ mice fed with HFD (Fig. 2B). Western blot analysis revealed that the expression of HIF-2 $\alpha$ and ANP was significantly decreased in the PHD2 ${ }^{\mathrm{EC}} \mathrm{KO}$ mice fed with HFD (Fig 4A and 4B). The expression of PFKFB3 and Akt had no significant difference between the control PHD2 ${ }^{\mathrm{f} / \mathrm{f}}$ mice and PHD2 ${ }^{\mathrm{EC}} \mathrm{KO}$ mice fed with HFD (Fig. $4 \mathrm{C}$ and $4 \mathrm{D}$ ). The expression of Ang-2 and TGF- $\beta$ was increased but did not reach a significant difference between the control PHD2 ${ }^{\mathrm{f} / \mathrm{f}}$ mice and PHD2 ${ }^{\mathrm{EC}} \mathrm{KO}$ mice fed with HFD (Fig. 4E and 4F).

\section{Discussion}

In the present study, we found that specific deletion of PHD2 in the endothelium resulted in a significant hepatic steatosis. This was accompanied by a significant increase in body

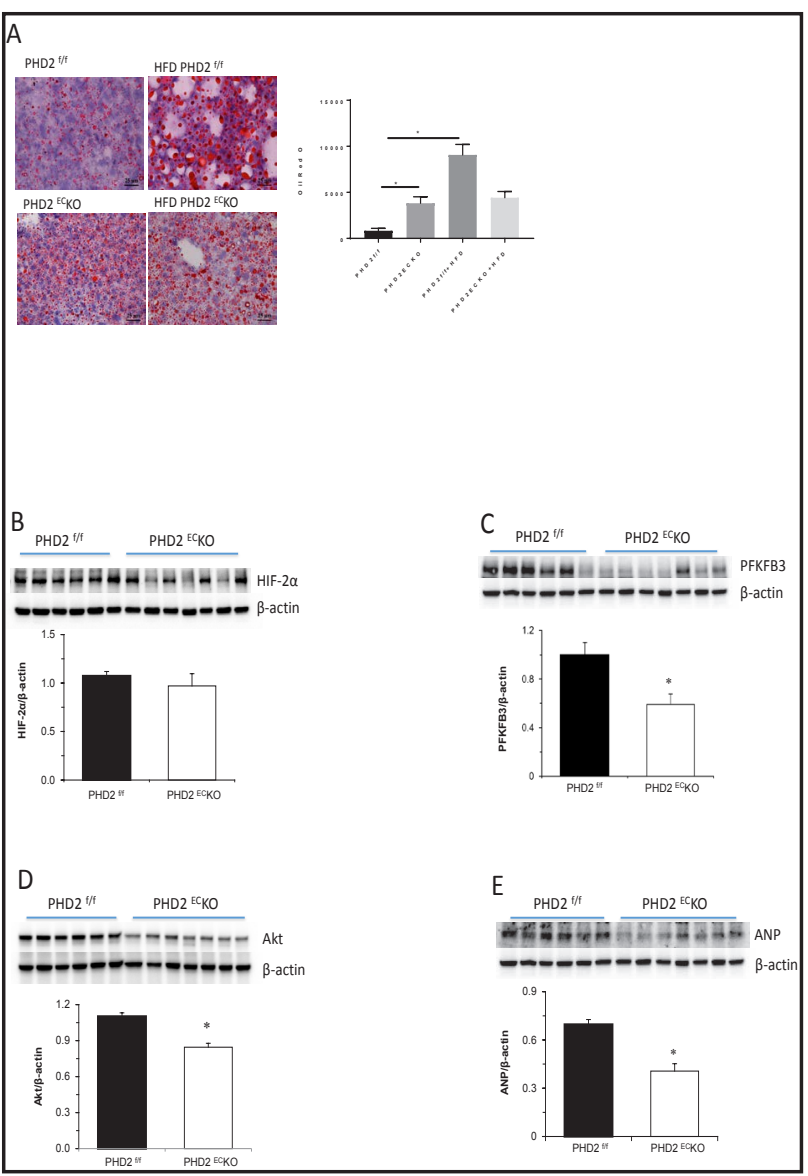

Fig. 1. $P H D 2^{\mathrm{EC}} \mathrm{KO}$ increases hepatic steatosis and regulates PFKFB3/Akt pathway. A) PHD2 ${ }^{\mathrm{EC}} \mathrm{KO}$ mice displayed a significant increase of red oil staining in liver $(n=6-7$ mice, $\left.{ }^{*} \mathrm{p}<0.05\right)$. PHD2 ${ }^{\mathrm{f} / \mathrm{f}}$ mice + HFD led to a significant increase of red oil staining in liver $\left(\mathrm{n}=6-7\right.$ mice, $\left.{ }^{*} \mathrm{p}<0.05\right)$. B) There was not a significant difference of HIF- $2 \alpha$ expression between the PHD2 ${ }^{\mathrm{f} / \mathrm{f}}$ and PHD2 ${ }^{\mathrm{EC}} \mathrm{KO}$ mice. ( $\mathrm{n}=6-7$ mice, $\left.{ }^{*} \mathrm{p}<0.05\right) . \mathrm{C}$ ) The expression of PFKFB3 was significantly decreased in the PHD2 ${ }^{\mathrm{EC}} \mathrm{KO}$ mice. ( $\mathrm{n}=6-7$ mice, $\left.{ }^{*} \mathrm{p}<0.05\right)$. D) The expression of Akt was significantly decreased in the PHD2 ${ }^{\mathrm{EC}} \mathrm{KO}$ mice. $(\mathrm{n}=6$ 7 mice, ${ }^{*} \mathrm{p}<0.05$ ). E) The expression of ANP was significantly decreased in the PHD2 ${ }^{\mathrm{EC}} \mathrm{KO}$ mice. $\left(\mathrm{n}=6-7\right.$ mice, $\left.{ }^{*} \mathrm{p}<0.05\right)$. Mean \pm SD, ${ }^{*} \mathrm{p}<0.05$. 
Fig. 2. $P H D 2{ }^{\mathrm{EC}} \mathrm{KO}$ increases hepatic fibrosis by regulating Ang-2/TGF- $\beta$ pathway. A) Masson trichrome staining showed that fibrosis around small arteries and venous, especially in the PHD2 ${ }^{\mathrm{EC}} \mathrm{KO}$ mice. The percentage of fibrotic area was significantly increased in the $\mathrm{PHD} 2^{\mathrm{EC}} \mathrm{KO}$ mice compared with the PHD2 ${ }^{\mathrm{f} / \mathrm{f}}$ mice. ( $n=6-7$ mice, ${ }^{*} \mathrm{p}<0.05$ ). B) The expression of Ang-2 was increased significantly in the

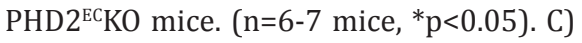
The expression of TGF- $\beta$ was significantly upregulated in the PHD $2{ }^{\mathrm{EC}} \mathrm{KO}$ mice. $(\mathrm{n}=6-7$ mice, ${ }^{*} p<0.05$ ). D) The expression of PHD2 was abolished in cultured EC from the $\mathrm{PHD}^{\mathrm{EC}} \mathrm{KO}$ mice. Mean \pm SD, ${ }^{*} \mathrm{p}<0.05$.

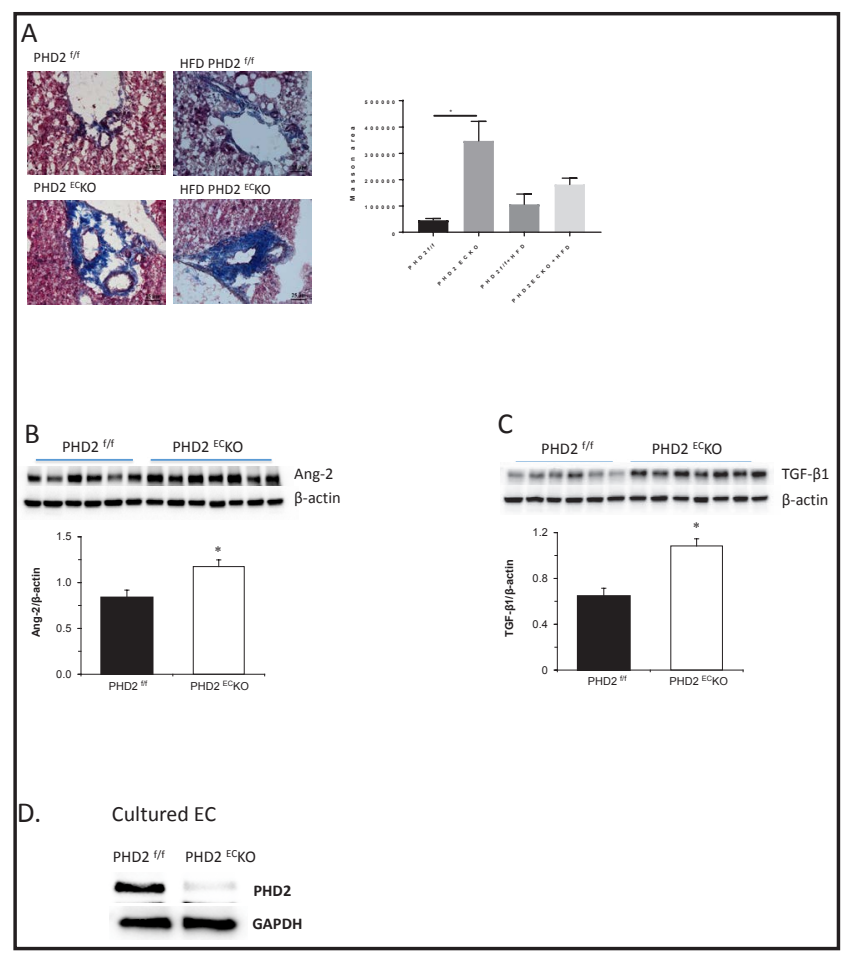

Fig. 3. $\mathrm{PHD} 2^{\mathrm{EC}} \mathrm{KO}$ increases body fat accumulation and impairs glucose tolerance. A) FW/BW ratio was significantly increased in the $\mathrm{PHD} 2{ }^{\mathrm{EC}} \mathrm{KO}$ mice and $\mathrm{PHD}^{\mathrm{f} / \mathrm{f}}$ mice + HFD compared with the $\mathrm{PHD}^{\mathrm{f} / \mathrm{f}}$ mice. FW/BW ratio was significantly increased in the PHD2 ${ }^{\mathrm{EC}} \mathrm{KO}$ mice + HFD compared with the PHD $2{ }^{\mathrm{EC}} \mathrm{KO}$ mice ( $n=7-9$ mice, $\left.{ }^{*} \mathrm{p}<0.05\right)$. B) Glucose tolerance was impaired in the PHD2 ${ }^{\mathrm{EC}} \mathrm{KO}$ mice compared with the PHD $2^{\mathrm{f} / \mathrm{f}}$ mice ( $\mathrm{n}=4$ mice, ${ }^{*} \mathrm{p}<0.05$ ).

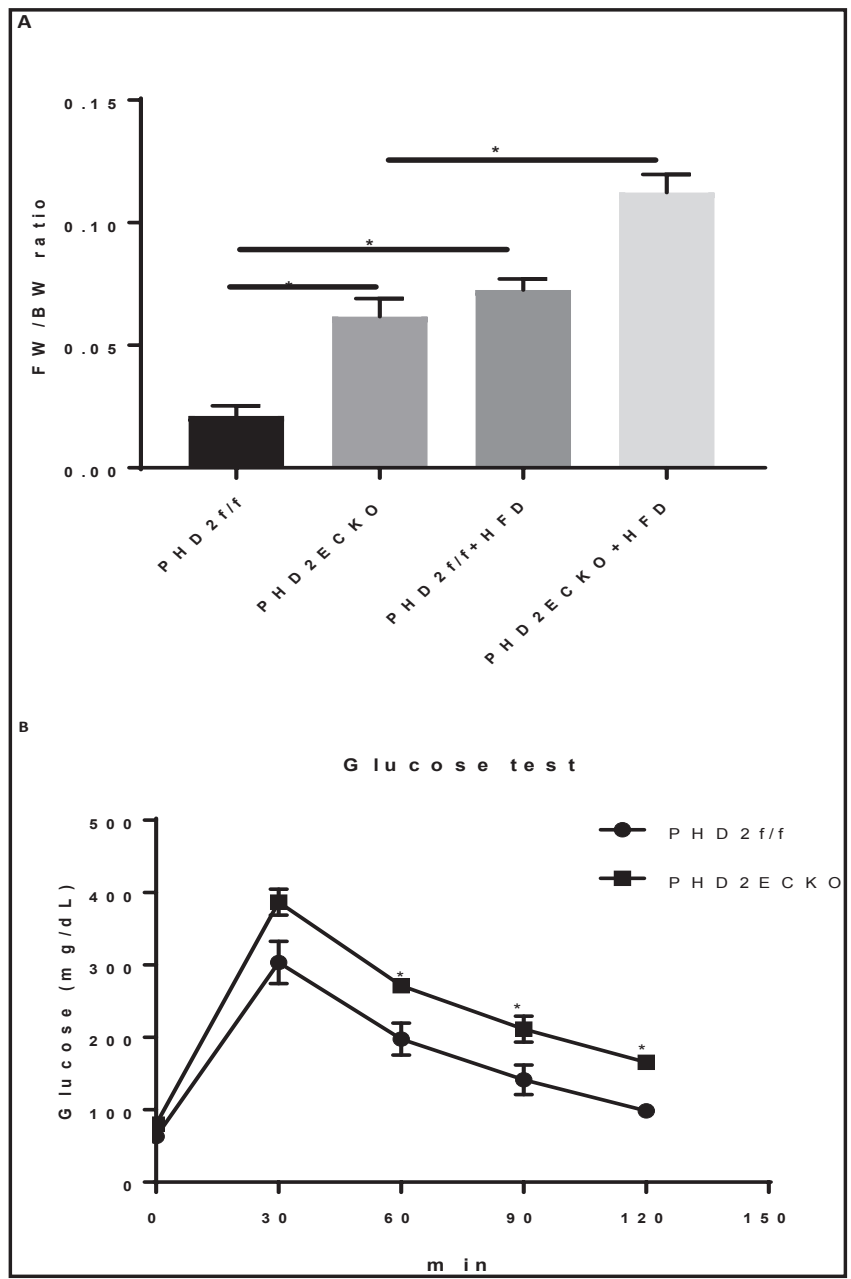


fat accumulation and impaired glucose tolerance in the mice. Furthermore, knockout of PHD2 in EC led to perivascular fibrosis. Mechanistically, knockout of PHD2 in EC downregulates ANP and upregulates Ang-2/TGF- $\beta$ expression in liver that may promote hepatic steatosis and fibrosis. Our results suggest a regulatory role of endothelial PHD2 in the hepatic steatosis and fibrosis via a HIF-2 $\alpha$ independent pathway.

Activation of HIF- $2 \alpha$ has been shown to result in suppression of fatty acid $\beta$-oxidation and lipid synthesis as well as an increase in lipid storage [27]. It is HIF-2 $\alpha$, not HIF-1 $\alpha$, which suppresses fatty acid oxidation and promotes lipid accumulation [27]. HIF-2 $\alpha$ controls at least three components of hepatic lipid metabolism: synthesis, oxidation, and storage [27]. Our present study showed that deletion of PHD2 in EC led to a lipid accumulation and fibrosis in the liver. Moreover, HIF-2 $\alpha$ seemed to not be involved in this process since we failed to

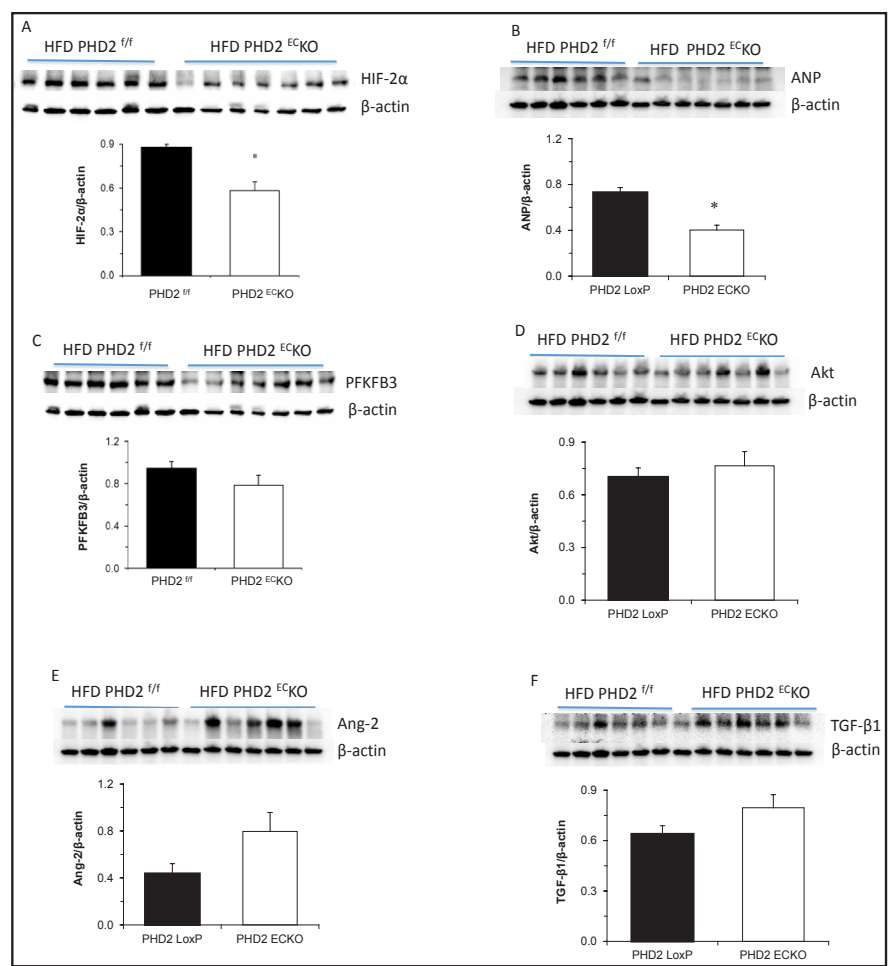

Fig. 4. $\mathrm{PHD}{ }^{\mathrm{EC}} \mathrm{KO}$ on HFD-induced liver gene expression. A) The expression of HIF- $1 \alpha$ was significantly decreased in the PHD $2{ }^{\mathrm{EC}} \mathrm{KO}$ mice + HFD compared with the PHD2 ${ }^{\mathrm{f} / \mathrm{f}}$ mice + HFD ( $\mathrm{n}=6-7$ mice, $\left.{ }^{*} \mathrm{p}<0.05\right)$. B) The expression of ANP was significantly decreased in the PHD2 ${ }^{\mathrm{EC}} \mathrm{KO}$ mice + HFD compared with the PHD2 ${ }^{\mathrm{f} / \mathrm{f}}$ mice + HFD ( $n=6-7$ mice, $\left.{ }^{*} \mathrm{p}<0.05\right)$. C-F) No significant difference of PFKFB3, Akt, Ang- 2 and TGF- $\beta$ are found between the PHD2 ${ }^{\mathrm{EC}} \mathrm{KO}$ mice + HFD and the $\mathrm{PHD}^{\mathrm{f} / \mathrm{f}}$ mice + HFD groups. ( $\mathrm{n}=6-7$ mice, $\left.{ }^{*} \mathrm{p}<0.05\right)$. Mean $\pm \mathrm{SD},{ }^{*} \mathrm{p}<0.05$. detect an increase in HIF-2 $\alpha$ expression in the liver tissues of PHD2 ${ }^{\mathrm{EC}} \mathrm{KO}$ mice. This may be due to PHD2 was a specific knockout in the endothelium and HIF-2 $\alpha$ was increased only in EC but not in the liver. PHD2 has been shown to regulate HIF-independent pathways by interacting with other substrates such as NDRG3 [24]. Our present study also indicates that the regulatory role of endothelial PHD2 on hepatic steatosis is mediated by a HIF- $2 \alpha$-independent pathway.

In the present study, we found that ANP was significantly suppressed in the liver of PHD2 ${ }^{\mathrm{EC}} \mathrm{KO}$ mice as well as in the PHD2 ${ }^{\mathrm{EC}} \mathrm{KO}$ mice fed with high fat diet. ANP is a peptidehormone produced mainly by cardiac atrium, ventricles of the heart, and vascular endothelial cells. ANP plays an important role in cardiovascular homeostasis by regulation of blood pressure [28-30]. Emerging evidence indicates a critical role of ANP in the regulation of lipid metabolism. ANP has been shown to reduce lipid accumulation by the mechanisms involved in promoting lipogenesis, lipid oxidation, and lipid mobilization [31-33]. ANP deficiency was observed in metabolic syndrome including type 2 diabetes, obesity, and NAFLD suggesting an involvement of ANP in the pathophysiology of metabolic disease [29-31]. Moreover, reduction of ANP expression has been contributed to lipid accumulation in diabetes [32]. ANP is also the most potent activator of adipocyte lipolysis, and ANP-mediated lipolysis is significantly impaired in type 2 diabetic patients and in obese humans [33-35]. Our data showed that PHD2 ${ }^{\mathrm{EC}} \mathrm{KO}$ mice fed with HFD had similar degree of lipid accumulation in the liver as fed with normal diet. In addition, ANP was downregulated in the liver of PHD2 ${ }^{\mathrm{EC}} \mathrm{KO}$ mouse either on normal diet or high fat diet which suggested a direct role of endothelial 
PHD2 on ANP expression that may not be associated with HFD-mediated lipid accumulation. Based upon these results, we postulated that reduction of ANP levels in PHD2 ${ }^{\mathrm{EC}} \mathrm{KO}$ mice may be attributed to hepatic lipid accumulation. In addition, the downregulation of ANP not only impacted the liver but may also be associated with body fat accumulation.

Ang-2 is predominately released by endothelial cells. Studies have shown that endothelial derived Ang-2 expression is regulated primarily by endothelial HIF-2 $\alpha$ [36]. Our previous studies demonstrated that specific knockout of endothelial PHD2 promotes HIF- $2 \alpha$ accumulation and upregulates Ang-2 expression. Upregulation of endothelial Ang-2 increases perivascular region of fibrosis in the lung and kidney of the PHD2 ${ }^{\mathrm{EC}} \mathrm{KO}$ mice [21, 22]. Consistent with these studies, the expression of Ang- 2 in liver tissues was also increased significantly in the PHD2 ${ }^{\mathrm{EC}} \mathrm{KO}$ mice. This may result in significant hepatic fibrosis in the perivascular region of PHD2 ${ }^{\mathrm{EC}} \mathrm{KO}$ mice. TGF- $\beta$ is a "master switch" in the differentiation of myofibroblasts in many tissues. We found that the expression of TGF- $\beta$ was significantly increased in the PHD2 ${ }^{\mathrm{EC}} \mathrm{KO}$ mice. Our previous studies have provided evidence that activation of TGF- $\beta$ signaling pathway may contribute to pericyte differentiation into myofibroblasts and fibrosis in the PHD2 ${ }^{\mathrm{EC}} \mathrm{KO}$ mice $[21,22]$. Therefore, increased Ang- 2 and TGF- $\beta$ in the liver tissues may be responsible for hepatic fibrosis in the PHD2 ${ }^{\mathrm{EC}} \mathrm{KO}$ mice. In addition, inhibition of PFKFB3 has been shown to increase Ang-2 expression in the EC [37]. Treatment with ANP has been shown to reduce liver fibrosis [38]. Downregulation of ANP and PFKFB3 expression in the PHD2 ${ }^{\mathrm{EC}} \mathrm{KO}$ mice may also contribute, at least in part, to the development of hepatic fibrosis.

Our data also showed that knockout of PHD2 in EC dramatically increased body fat accumulation under high-fat diet stress. Surprisingly, deletion of endothelial PHD2 did not accentuate HFD-induced hepatic steatosis and fibrosis. So far, the underlying mechanism of endothelial PHD2 in HFD stress remains unknown. Upregulation of liver HIF- $2 \alpha$ has been reported to increase lipid accumulation [27]. In contrast to PHD2 ${ }^{\mathrm{EC}} \mathrm{KO}$ mice on normal diet, PHD2 ${ }^{\mathrm{EC}} \mathrm{KO}$ mice fed with HFD had a significant reduction of HIF-2 $\alpha$ in the liver. Further investigations are warrant to clarify the mechanisms and determine whether reduction of liver HIF- $2 \alpha$ contributes HFD-induced hepatic steatosis.

In summary, endothelium is one of the most complicated systems of the body; its function is regulated precisely at the gene levels as well as by metabolic stress. Further investigations should be done to clarify the precise mechanism of the regulation of endothelial PHD2 on lipid metabolism. PHD2 and HIF- $2 \alpha$-independent pathway in the endothelium may be a therapeutic target candidate for chronic liver disease inducing to steatosis and fibrosis.

\section{Acknowledgements}

We thank Dr. Guo-hua Fong for providing PHD2 ${ }^{\mathrm{f} / \mathrm{f}}$ mice. We thank Miss. Rebecca Worsham for editing this manuscript. This study was supported by grants from NIH grant 2R01HL102042 and University of Mississippi Medical Center Intramural Research Support Program to J.X. Chen.

\section{Disclosure Statement}

The authors have no conflicts of interest associated with this manuscript.

\section{References}

\footnotetext{
1 Gao B, Bataller R: Alcoholic liver disease: pathogenesis and new therapeutic targets. Gastroenterology 2011;141:1572-1585.

-2 Cohen JC, Horton JD, Hobbs HH: Human fatty liver disease: old questions and new insights. Science 2011;332:1519-1523.
} 


\section{Cellular Physiology Cell Physiol Biochem 2018;48:1003-1011 \begin{tabular}{l|l} 
and Biochemistry Published online: July 23, 2018 & $\begin{array}{l}\text { (c) } 2018 \text { The Author(s). Published by S. Karger AG, Basel } \\
\text { www.karger.com/cpb }\end{array}$ \\
\hline
\end{tabular}

3 Savage DB, Semple RK: Recent insights into fatty liver, metabolic dyslipidaemia and their links to insulin resistance. Curr Opin Lipidol 2010;21:329-336.

4 Tilg H, Moschen AR: Insulin resistance, inflammation, and non-alcoholic fatty liver disease. Trends Endocrinol Metab 2008;19:371-379.

-5 Gordon GB, Barcza MA, Bush ME: Lipid accumulation of hypoxic tissue culture cells. Am J Pathol 1977;88:663-678.

-6 Whitmer JT, Idell-Wenger JA, Rovetto MJ, Neely JR, J.: Control of fatty acid metabolism in ischemic and hypoxic hearts. J Biol Chem 1978;253:4305-4309.

-7 Piguet AC, Stroka D, Zimmermann A, Dufour JF: Hypoxia aggravates non-alcoholic steatohepatitis in mice lacking hepatocellular PTEN. Clin Sci (Lond) 2009;118:401-410.

-8 Saarikoski ST, Rivera SP, Hankinson 0: Mitogen-inducible gene 6 (MIG-6), adipophilin and tuftelin are inducible by hypoxia. FEBS Lett 2002;530:186-190.

-9 Parathath S, Mick SL, Feig JE, Joaquin V, Grauer L, Habiel DM, Gassmann M, Gardner LB, Fisher EA: Hypoxia is present in murine atherosclerotic plaques and has multiple adverse effects on macrophage lipid metabolism. Circ Res 2011;109:1141-1152.

-10 Furuta E, Pai SK, Zhan R, Bandyopadhyay S, Watabe M, Mo Y-Y, Hirota S, Hosobe S, Tsukada T, Miura K, Kamada S, Saito K, Iiizumi M, Liu W, Ericsson J, Watabe K: Fatty acid synthase gene is up-regulated by hypoxia via activation of Akt and sterol regulatory element binding protein-1. Cancer Res 2008;68:10031011.

11 Pinthus JH, Whelan KF, Gallino D, Lu JP, Rothschild N: Metabolic features of clear-cell renal cell carcinoma: mechanisms and clinical implications. Can Urol Assoc J 2011;5:274-282.

12 Haase VH, Glickman JN, Socolovsky M, Jaenisch R: Vascular tumors in livers with targeted inactivation of the von Hippel-Lindau tumor suppressor. Proc Natl Acad Sci U S A 2001;98:1583-1588.

-13 Ma W, Tessarollo L, Hong SB, Baba M, Southon E, Back TC, Spence S, Lobe CG, Sharma N, Maher GW, Pack S, Vortmeyer AO, Guo C, Zbar B, Schmidt LS: Hepatic vascular tumors, angiectasis in multiple organs, and impaired spermatogenesis in mice with conditional inactivation of the VHL gene. Cancer Res 2003;63:5320-5328.

14 Epstein AC, Gleadle JM, McNeill LA, Hewitson KS, O’Rourke J, Mole DR, Mukherji M, Metzen E, Wilson MI, Dhanda A, Tian YM, Masson N, Hamilton DL, Jaakkola P, Barstead R, Hodgkin J, Maxwell PH, Pugh CW, Schofield CJ, Ratcliffe PJ: C. elegans EGL-9 and mammalian homologs define a family of dioxygenases that regulate HIF by prolyl hydroxylation. Cell 2001;107:43-54.

15 Ivan M, Kondo K, Yang H, Kim W, Valiando J, Ohh M, Salic A, Asara JM, Lane WS, Kaelin WG, Jr: HIFalpha targeted for VHL-mediated destruction by proline hydroxylation: implications for 02 sensing. Science 2001;292:464-468.

16 Jaakkola P, Mole DR, Tian YM, Wilson MI, Gielbert J, Gaskell SJ, von Kriegsheim A, Hebestreit HF, Mukherji M, Schofield CJ, Maxwell PH, Pugh CW, Ratcliffe PJ: Targeting of HIF-alpha to the von Hippel-Lindau ubiquitylation complex by 02-regulated prolyl hydroxylation. Science 2001;292:468-472.

17 Maxwell PH, Wiesener MS, Chang GW, Clifford SC, Vaux EC, Cockman ME, Wykoff CC, Pugh CW, Maher ER, Ratcliffe PJ: The tumour suppressor protein VHL targets hypoxia-inducible factors for oxygen-dependent proteolysis. Nature 1999;399:271-275.

18 Appelhoff RJ, Tian YM, Raval RR, Turley H, Harris AL, Pugh CW, Ratcliffe PJ, Gleadle JM: Differential function of the prolyl hydroxylases PHD1, PHD2, and PHD3 in the regulation of hypoxia-inducible factor. J Biol Chem 2004;279:38458-38465.

19 Berra E, Benizri E, Ginouvès A, Volmat V, Roux D, Pouysségur J: HIF prolyl-hydroxylase 2 is the key oxygen sensor setting low steady-state levels of HIF-1alpha in normoxia. The EMBO journal 2003;22:4082-4090.

20 Lieb ME, Menzies K, Moschella MC, Ni R, Taubman MB: Mammalian EGLN genes have distinct patterns of mRNA expression and regulation. Biochem Cell Biol 2002;80:421-426.

21 Wang S, Zeng H, Chen ST, Zhou L, Xie XJ, He X, Tao YK, Tuo QH, Deng C, Liao DF, Chen JX: Ablation of endothelial prolyl hydroxylase domain protein-2 promotes renal vascular remodelling and fibrosis in mice. J Cell Mol Med 2017;21:1967-1978.

22 Wang S, Zeng H, Xie XJ, Tao YK, He X, Roman RJ, Aschner JL, Chen JX: Loss of prolyl hydroxylase domain protein 2 in vascular endothelium increases pericyte coverage and promotes pulmonary arterial remodeling. Oncotarget 2016;7:58848-58861. 


\section{Cellular Physiology Cell Physiol Biochem 2018;48:1003-1011 \begin{tabular}{l|l} 
DOI: 10.1159/000491968 & $\begin{array}{l}\text { O 2018 The Author(s). Published by S. Karger AG, Basel } \\
\text { www.karger.com/cpb }\end{array}$
\end{tabular} \\ Zhou et al.: Endothelial PHD2 and Hepatic Steatosis}

23 Elvidge GP, Glenny L, Appelhoff RJ, Ratcliffe PJ, Ragoussis J, Gleadle JM: Concordant regulation of gene expression by hypoxia and 2-oxoglutarate-dependent dioxygenase inhibition: the role of HIF-1alpha, HIF2alpha, and other pathways. J Biol Chem 2006;281:15215-15226.

24 Lee DC, Sohn HA, Park ZY, Oh S, Kang YK, Lee KM, Kang M, Jang YJ, Yang SJ, Hong YK, Noh H, Kim JA, Kim DJ, Bae KH, Kim DM, Chung SJ, Yoo HS, Yu DY, Park KC, Yeom YI: A lactate-induced response to hypoxia. Cell 2015;161:595-609.

25 Zeng L, Tang W, Yin J, Feng L, Li Y, Yao X, Zhou B: Alisol A 24-Acetate Prevents Hepatic Steatosis and Metabolic Disorders in HepG2 Cells. Cell Physiol Biochem 2016;40:453-464.

26 Wang L, Zhang N, Wang Z, Ai D-M, Cao Z-Y, Pan H-P: Decreased MiR-155 Level in the Peripheral Blood of Non-Alcoholic Fatty Liver Disease Patients may Serve as a Biomarker and may Influence LXR Activity. Cell Physiol Biochem 2016;39:2239-2248.

27 Rankin EB, Rha J, Selak MA, Unger TL, Keith B, Liu Q, Haase VH: Hypoxia-inducible factor 2 regulates hepatic lipid metabolism. Mol Cell Biol 2009;29:4527-4538.

28 Santhekadur PK, Kumar DP, Seneshaw M, Mirshahi F, Sanyal AJ: The multifaceted role of natriuretic peptides in metabolic syndrome. Biomed Pharmacother 2017;92:826-835.

29 Moro C: Targeting cardiac natriuretic peptides in the therapy of diabetes and obesity. Expert Opin Ther Targets 2016;20:1445-1452.

-30 Schlueter N, de Sterke A, Willmes DM, Spranger J, Jordan J, Birkenfeld AL: Metabolic actions of natriuretic peptides and therapeutic potential in the metabolic syndrome. Pharmacol Ther 2014;144:12-27.

-31 Souza SC, Chau MD, Yang Q, Gauthier MS, Clairmont KB, Wu Z, Gromada J, Dole WP: Atrial natriuretic peptide regulates lipid mobilization and oxygen consumption in human adipocytes by activating AMPK. Biochem Biophys Res Commun 2011;410:398-403.

-32 Bartels ED, Nielsen JM, Bisgaard LS, Goetze JP, Nielsen LB: Decreased expression of natriuretic peptides associated with lipid accumulation in cardiac ventricle of obese mice. Endocrinology 2010;151:5218-5225.

-33 Dessi-Fulgheri P, Sarzani R, Rappelli A: Role of the natriuretic peptide system in lipogenesis/lipolysis. Nutr Metab Cardiovasc Dis. 2003;13:244-249.

34 Verboven K, Hansen D, Moro C, Eijnde BO, Hoebers N, Knol J, Bouckaert W, Dams A, Blaak EE, Jocken JW: Attenuated atrial natriuretic peptide-mediated lipolysis in subcutaneous adipocytes of obese type 2 diabetic men. Clin Sci (Lond) 2016;130:1105-1114.

-35 Ryden M, Backdahl J, Petrus P, Thorell A, Gao H, Coue M, Langin D, Moro C, Arner P: Impaired atrial natriuretic peptide-mediated lipolysis in obesity. Int J Obes (Lond) 2016;40:714-720.

-36 Skuli N, Majmundar AJ, Krock BL, Mesquita RC, Mathew LK, Quinn ZL, Runge A, Liu L, Kim MN, Liang J, Schenkel S, Yodh AG, Keith B, Simon MC: Endothelial HIF-2 $\alpha$ regulates murine pathological angiogenesis and revascularization processes. J Clin Invest. 2012;122:1427-1443.

-37 He X, Zeng H, Chen ST, Roman RJ, Aschner JL, Didion S, Chen JX: Endothelial specific SIRT3 deletion impairs glycolysis and angiogenesis and causes diastolic dysfunction. J Mol Cell Cardiol 2017;112:104-113.

-38 Ishigaki N, Yamamoto N, Jin H, Uchida K, Terai S, Sakaida I: Continuos intravenous infusion of atrial natriuretic peptide (ANP) prevented liver fibrosis in rat. Biochem Biophys Res Commun 2009;378:354359. 